\title{
Mortgage volume and macroeconomic factors: Evidence from Turkey
}

Mortgage kredi hacmi ve makroekonomik faktörler: Türkiye örneği

\author{
Tuğba Güneş ${ }^{1}$ \\ Ayşen Apaydın²
}

${ }^{1}$ PhD Candidate, Ankara University, Graduate School of Natural and Applied Sciences, Department of Real Estate Development and Management, Ankara, Turkey, gunest@ankara.edu.tr,

ORCID: 0000-0002-7472-1017

2 Prof. Dr., Ankara University, Faculty of Applied Sciences, Department of Actuarial Sciences, Ankara, Turkey, aapaydin@ankara.edu.tr,

ORCID: 0000-0003-4683-0459

\section{Corresponding Author:}

Tuğba Güneş,

Ankara University, Ankara, Turkey, gunest@ankara.edu.tr

Submitted: $10 / 09 / 2021$

Revised: 24/10/2021

Accepted: 9/11/2021

Online Published: 25/12/2021

Citation: Güneş, T., \& Apaydın, A., Mortgage volume and macroeconomic factors: Evidence from Turkey, bmij (2021) 9 (4): 1504-1520, doi: https://doi.org/10.15295/bmij.v9i4.1939

\begin{abstract}
This paper investigates the impacts of several macroeconomic variables on Turkey's volume of mortgage loans. Johansen cointegration test, vector error correction model, Granger causality tests, variance decomposition, and impulse-response analysis is employed for the econometric analysis to show short and long-run relationships between the variables using time series monthly data from January 2010 to March 2020. Paper results demonstrate that growth of housing credit size negatively correlates with mortgage interest rates, US Dollar/Turkish Lira exchange rate and level of real estate supply. At the same time, there is a positive correlation with house prices. Causal relationships between mortgage volume and macroeconomic indicators are bidirectional for all variables, except for mortgage interest rates. There is a one-way causality relationship from mortgage rates to mortgage loan volume. Econometric analyses show that the recent steep depreciation in the Turkish Lira hurts the Turkish mortgage market. In conclusion, a stable economic environment is essential to build a robust mortgage market.
\end{abstract}

Keywords: Mortgage Loan Volume, Housing Finance, Macroeconomy, Turkey

Jel Codes: C32, R31, E44

Öz

Bu çalışmada, Türkiye' de çeşitli makroekonomik göstergelerin mortgage kredi hacmi üzerindeki etkileri Ocak-2010 ve Mart-2020 dönemi için incelenmiştir. Değişkenler arasındaki kısa ve uzun dönemli ilişkilerin ekonometrik analizleri için Johansen eşbütünleşme analizi, vektör hata düzeltme modeli, Granger nedensellik testleri, varyans ayrıştırması ve etki-tepki analizleri uygulanmıştır. Yapılan analizler sonucunda, mortgage kredi hacminin, konut kredisi faiz oranları, Amerikan DolarıTürk Lirası kuru ve bina arzı ile negatif yönlü, konut fiyatları ile ise pozitif yönlü anlamlı bir ilişkiye sahip olduğu belirlenmiştir. Mortgage kredi hacmi ile kredi faiz oranı haricindeki tüm makroekonomik değişkenler arasında çift yönlü nedensellik ilişkileri vardır, mortgage faiz oranlarından mortgage kredi büyüklüğüne doğru ise tek yönlü nedensellik ilişkisi olduğu görülmüştür. Ekonometrik analizler, Türk Lirasının son yıllarda yaşadığı değer kaybının Türk mortgage piyasasını negatif yönde etkilediğini de açıkça göstermektedir. Sonuç olarak, sağlam bir mortgage piyasasının oluşturulması için istikrarlı bir ekonomi elzemdir.

Anahtar Kelimeler: Mortgage Kredi Hacmi, Konut Finansmanı, Makroekonomi, Türkiye

JEL Kodları: C32, R31, E44 


\section{Introduction}

Housing is one of the basic human needs, and the lack of adequate housing is a significant challenge in many countries today. There are various housing finance systems adopted in different markets across the world. International organizations, governments, agencies and other related actors try to find the best solutions to increase the number of new products and services in housing finance, enabling people to afford the cost of housing as easy as possible. Affordable and adequate housing for everyone is one of the significant components of the 2030 Agenda for sustainable development. It takes place in many global strategies, from New Urban Agenda to Paris Climate Change Agreement (Habitat, 2021).

Based on lessons learned in well-developed countries, Turkey has started to establish a mortgage system with the entrance into force of the Housing Finance System Law (No. 5582) in 2007. Afterwards, fundamental principles for the secondary mortgage market have been determined with the new Capital Market Law (No. 6362) enacted in 2012 and various communiqués published by the Capital Market Board in the framework of this Law. Interestingly enough, the volume of mortgage loans in Turkey has been showing a growing trend with some fluctuations, even though the main reason for the tremendous economic crisis in the USA in 2007 was the mortgage system. On the other hand, the share of mortgage loans in the gross domestic product (GDP) is too low even though the Turkish mortgage system has completed more than a decade as of today. Various factors could be the reasons for such low-speed development. However, Yalciner (2006) states that there are two essential preconditions for creating a well-functioning mortgage system in a country; (1) a stable and sustainable economic environment that enables affordable mortgage loans with extended terms, and (2) the existence of legislative regulations and technical conditions for the institutionalization of the market. In this study, by moving from the first prerequisite, we try to show the relationship between critical macroeconomic indicators and mortgage loan volume in Turkey.

This paper uses a vector error correction model to estimate the relationship between the volume of mortgage loans and some of the key macroeconomic indicators chosen based on the Turkish mortgage market and findings in the related literature. By using time series monthly data from January 2010 to March 2020, the cointegration test shows that there is a long-run relationship between the volume of mortgage loans and mortgage interest rates, house price index, industrial production index, number of construction permits and US Dollar/Turkish Lira exchange rate in Turkey. The shortness of the period since the Turkish mortgage system has been newly developed and the lack of local economic variables are the significant limitations of our data. However, this study may serve as one of the bases for future papers on the same topic as long as the Turkish mortgage system continues to progress.

The remainder of the paper proceeds as follows: Section 2 reviews the existing literature; Section 3 provides information on Turkish macroeconomic conditions and mortgage market; Section 4 presents the data and econometric methods used in this paper and results of the empirical analysis concurrently, and the last section concludes the article.

\section{Literature review}

Strong legal regulations, deeper credit information systems and stable macroeconomic conditions are significant well-developed housing finance systems. However, the lack of these factors explains a vast portion of the variations in housing finance systems in developing countries (Warnock \& Warnock, 2008). Similarly, Chiquier and Lea (2009) state that significant drivers of housing finance systems in emerging countries are favourable macroeconomic conditions, increasing housing demand because of rapid urbanization and demographic changes, and financial liberalization. But, on the other hand, a well-functioning housing finance system is an essential contributor to economic growth and urban development in a country (Renaud, 1999).

There are multiple housing finance systems. However, the mortgage system is the primary approach adopted in many countries today. The development of a mortgage market initially requires a stable economy and the establishment of the sector. The following steps are expanding the primary market and creating a secondary mortgage market. Thus, the mortgage market is related to borrowers and lenders and has a vital role for investors. There is extensive literature on analyzing and modelling relationships among the mortgage market growth and macroeconomic factors. This chapter provides a brief literature review on related topics, mainly focusing on the studies on emerging markets published in recent years.

Calza, Gartner, and Sousa (2001) found that long-term loans co-integrate with GDP positively and with interest rates negatively in their study analyzing the determinants of loans in the Euro area by using Johansen methodology. Similar to Calza et al. (2001), Gattin-Turkalj, Ljubaj, Martinis, and Mrkalj (2007), 
by using the OLS method, suggests that credit demand in Croatia is explained with GDP and real interest rates. Adams and Füss (2010) examined the impacts of macroeconomic determinants on international housing prices. Their panel cointegration analysis for 15 countries suggests that macroeconomic variables significantly impact house prices. Jen-Shi, Shuen-Shi, and Yu (2012) built a vector autoregressive (VAR) model which explains the United States (US) housing market index with unemployment rate, consumer confidence index, FED interest rate and Dow Jones industry index. According to a restricted error correction model for Swedish panel data, Hort (1998) found house prices are affected by movements of income, user cost and construction costs. Erjona (2014) stated that house prices in Albania show a rapid increase with the fast expansion of mortgage loans. Panagiotidis and Printzis (2016) studied the long-run determinants of the housing market in Greece by using VECM (vector error correction model) estimation approach. Arestis and González (2014) brought a theoretical model to identify the main drivers of house prices and applied this model to 18 OECD countries from 1970 through 2011. In addition to most common variables such as income, interest rates, etc., they include the role of fiscal and monetary authorities in the study. Akkay (2021) showed that significant dynamics of house prices in Turkey are mortgage interest rates, USD/TL exchange rate and employment level in the country. Unlike many other countries, government intervention is the fundamental driver of the housing market in China, however, Duan, Tian, Yang, and Zhou (2021) found that macroeconomic factors still have impacts on the housing prices in the country. Their VAR model indicates that both money supply and mortgage interest rates effect the housing prices in Beijing in the long term.

Even though there is evolving literature focusing directly on the growth of mortgage loans and their macroeconomic drivers, it is not as extensive as the studies on house price dynamics. Addae-Dapaah (2014) used Johansen cointegration and VECM and showed the long-run cointegration among housing loans, house price, GDP and interest rates. Their analysis covers the period of 1991 to 2010 in Singapore. While housing loans positively correlates with house prices and GDP, this correlation becomes negative with the interest rates. In their study, Mogaka, Kiweu, and Kamau (2015) studied the impacts of macroeconomic economic factors on the mortgage market expansion in Kenya. Their regression analysis showed that inflation, average GDP growth rate, Treasury bill rate and national savings rate significantly influence the total mortgage loan volume. Another research study by Shukor, Said, and Majid (2016) investigating the relationship of housing finance and macroeconomic variables for Malaysia by using vector autoregressive (VAR) modelling approach found a long-run relationship between the housing finance variable and GDP positively and interest rates negatively. Shahini (2014) analyzed the demand for housing loans in Albania by taking money supply and economic growth as the independent variables. Log-level regression analysis for the 2008-2013 period suggests strong relations among the variables. Ramesh and Kumar (2017) show the impacts of GDP, inflation, and interest rates on India's growth of nonperforming loans. Ahiadorme (2016) applied a multiple regression model for 2007-2015 and found that the macroeconomic environment has a crucial impact on the development of the Ghanaian mortgage market. Dajcman (2020) found that GDP growth, mortgage interest rates, housing prices are significant determinants of residential mortgages in 13 European countries. There might be different dynamics of mortgage demand in well-developed countries besides the economic indicators. For example, in their studies investigating mortgage and housing demands in the UK, Australia, and Japan, Naoi, Tiwari, Moriizumi, Yukutake, Hutchison, Koblyakova, and Rao (2019) found that mortgage demand is relatively higher in those countries with non-recourse loans than those with recourse loans. Demographic factors (age, increasing population), monetary policies and housing market conditions are counted among the drivers of mortgage demand.

Turning on the Turkish economy studies, Ucal and Gókkent (2009) employed a vector autoregression model to examine the macroeconomic factors affecting real estate markets in Turkey. They found that consumer price index, wages, interest rates and exchange rates affect house prices. They used a dummy variable to measure the effect of the 1999 earthquake. Hepsen and Bas (2009) examine dynamic casual relationships between consumer price index, monetary aggregate (M2), interest rate, industrial production index, real estate investment trusts index and volume of mortgage loans between 2002 and 2007. According to VAR and cointegration analysis with the data covering 2005-2012 period, İbicioğlu and Karan (2012) suggest that interest rates, unemployment and consumer confidence index affect the level of housing credit demand in Turkey. Yalciner and Coskun (2014) employed econometric analyses to see the relationships between the macroeconomic conditions and volume of housing credit. Based on the 2005-2011 period data, real interest rates, residential buildings floor area according to occupancy permits, real GDP per capita and monetary aggregate (M2) are co-integrated with housing credit in Turkey. Uysal and Yiğit (2016) use the Johansen cointegration test and suggest that GDP per capita, urbanization rate, interest rate and monetary aggregate (M2) have significant impacts on housing 
demand in Turkey for the 1970-2015 period. On the contrary of many recent studies about Turkey that mainly focus on economic drivers of either housing prices (e.g. Karadaş and Salihoğlu (2020), Coskun (2016)) or housing demand (e.g. Uysal and Yiğit (2016)), this study provides an insight about how the macroeconomic environment influences mortgage loan volume in Turkey.

\section{Macroeconomic indicators and mortgage market in Turkey}

Turkey hosts a population of almost 84 million, and out of $46 \%$, the population is under the age of 35 . The population growth rate was at around 13 per thousand per annum in the last decade while averagely 6 per thousand in OECD member countries. Besides, the country has been experiencing rapid urbanization; today, 93 per cent of the population lives in urban areas, only $38.5 \%$ in 1970 . As a result, household size has declined, down to $3.30 \%$ in 2020 from 5.69\% in the 1970s. Rising population, rapid urbanization and accompanying circumstances make "housing" one of the priorities in the country schedule (TurkStat, 2021a). On the other hand, when we look at the housing supply, official up-to-date statistics on the housing stock are unavailable in Turkey. According to the Turkish Statistical Institute (TurkStat) estimations based on the Address Based Population Registration System and statistics on the certificate of permission for building occupation and construction, approximately 36 million housing units (including dwellings, condominiums, etc., summer houses etc.) by $2017 .{ }^{1}$ The number of homes given the permission certificate for building occupation was around 326000 in 2007, reaching its maximum (895000) in 2018 and 600000 by 2020 (TurkStat, 2021b).

According to the official records of the Land Registry and Cadastre Agency, which is the only responsible institution for property transactions in Turkey, there is an active housing market in Turkey. There are more than two million property transactions annually, and more than $50 \%$ of these sales corresponds to house sales. With the entrance into force of Hosing Finance System Law (No. 5582) ${ }^{2}$ in 2007 and new Capital Market Law (No. 6362) in 2012, the mortgage system has been adopted as the housing finance system in the country and mortgaged sales has been started to take place in the market. As a result, the share of mortgaged sales increased in the first years and reached $40 \%$ in all house sales by 2013. Even though 2014 witnessed a decrease in housing sales with the mortgage, their share remained constant, 33\% between 2014 and 2017. However, in the following two years, the percentage of housing transactions with cash payments rose, which pushed the share of mortgages down to under $25 \%$. Parallel with several moves of the Turkish government to boost the economy and mitigate the adverse impacts of the COVID-19 pandemic, Tukey's state banks launched loan campaigns by decreasing interest rates significantly in mid-2020, and a noticeable rise was observed in mortgaged sales in 2020, as seen on Table 1 (TurkStat, 2021d).

Table 1: Housing Sales Statistics in Turkey

\begin{tabular}{|c|c|c|c|c|c|}
\hline Year & $\begin{array}{l}\text { \# of } \\
\text { House } \\
\text { Sales }\end{array}$ & $\begin{array}{l}\text { \# of } \\
\text { Mortgaged } \\
\text { Sales }\end{array}$ & Year & $\begin{array}{l}\text { \# of } \\
\text { House } \\
\text { Sales }\end{array}$ & $\begin{array}{l}\text { \# of } \\
\text { Mortgaged } \\
\text { Sales }\end{array}$ \\
\hline 2007 & $N A$ & $N A$ & 2014 & 1.165 .381 & 389.689 \\
\hline 2008 & 427.105 & $N A$ & 2015 & 1.289 .320 & 434.388 \\
\hline 2009 & 555.184 & 22.726 & 2016 & 1.341 .453 & 449.508 \\
\hline 2010 & 607.098 & 246.741 & 2017 & 1.409 .314 & 473.099 \\
\hline 2011 & 708.275 & 289.275 & 2018 & 1.375 .398 & 276.820 \\
\hline 2012 & 701.621 & 270.136 & 2019 & 1.348 .729 & 332.508 \\
\hline 2013 & 1.157 .190 & 460.112 & 2020 & 1.499 .316 & 573.337 \\
\hline
\end{tabular}

Housing is an integral part of people's wealth, and financing this asset usually requires additional funds since people's savings are insufficient to afford a home. Thus, housing finance systems becomes a significant element in an economy. Borrowers are interested in the affordability of loans while lenders are looking for getting acceptable risks. Ensuring an optimal balance between the two sides is quite challenging. Therefore, as most studies in the literature show, mortgage interest rates, in other words, the cost of mortgage loans, become a vital driver of the expansion of the mortgage market in emerging countries. A great majority of consumer loans, including mortgage credits, are provided mainly by Turkey's commercial banks. However, Turkish banks suffer from funding mismatches between shortterm liabilities (depositories) and long-term mortgage loans (bank assets). Thus, lack of a sufficient secondary mortgage market is a crucial factor that affects mortgage interest rates and consequently growth of the mortgage market significantly (Yalciner, 2006). Figure 1 shows the weighted average

\footnotetext{
1 Source: interviews with TurkStat experts

2 Source: Housing Finance System Law was repealed with the entrance into force of the new Capital Market Law.
} 
interest rates for banks housing loans in Turkey (CBRT, 2021b) and conventional conforming 15-year fixed-rate mortgage rates for the USA (Freddie Mac, 2021). As seen in the figure, mortgage interest rates in Turkey are averagely four times higher than those in the US, which is the leading country in terms of its primary and secondary mortgage market sizes globally, and this difference reached almost seven in 2018-Q4.

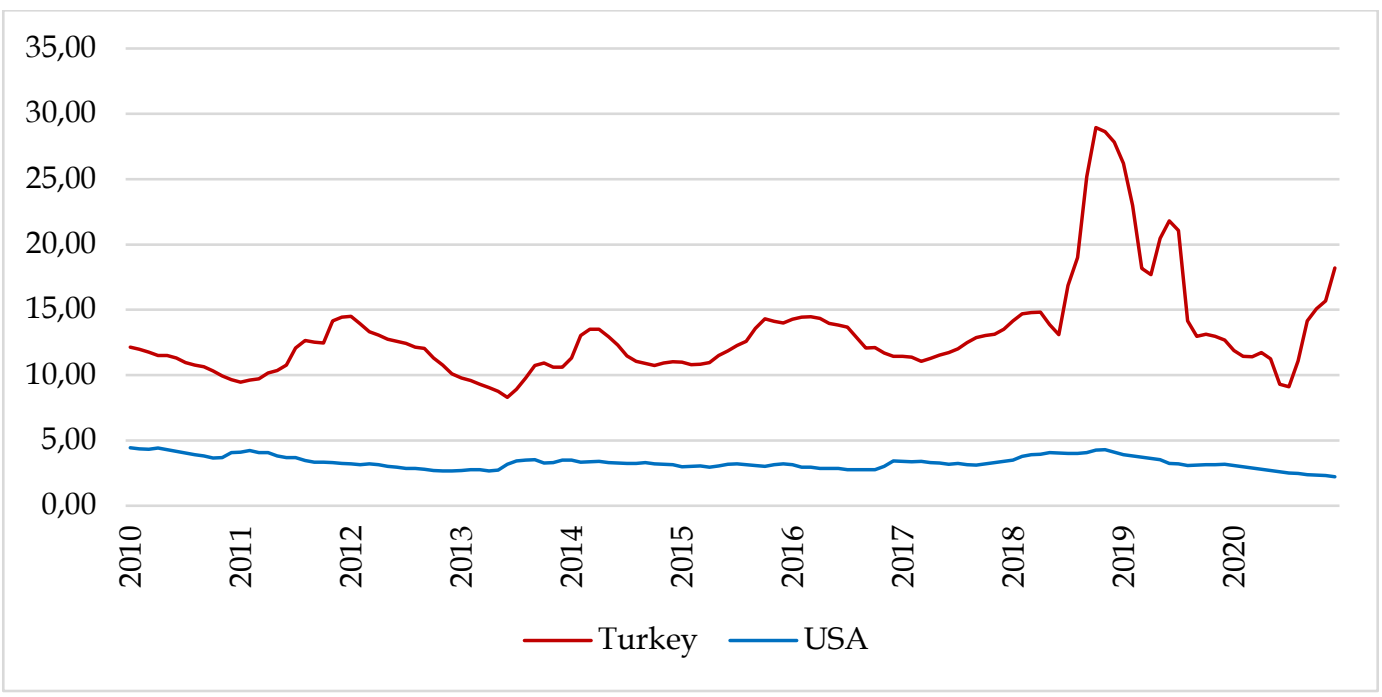

Figure 1: Mortgage Interest Rates in Turkey and the USA

Mortgage interest rates and house prices are undoubtedly significantly essential elements of any housing market and driving housing demand and supply factors. Therefore, people naturally pay close attention to house prices while buying homes and applying for mortgage loans. The House price index (HPI) has been produced by the Central Bank of the Republic of Turkey since 2010. This index is constructed using hedonic regression every month for 26 NUTS2 regions in compliance with the European Union Regional Statistics System. However, the Central Bank uses appraisal reports prepared by the valuation companies for mortgage and capital market purposes. Because official records kept by the Land Registry Offices do not reflect actual transaction prices as sellers and buyers avoid declaring accurate/valid prices to decrease transaction fees and tax liabilities (Güneş \& Yildiz, 2016; Hülagü, Kızılkaya, Özbekler, \& Tunar, 2016).

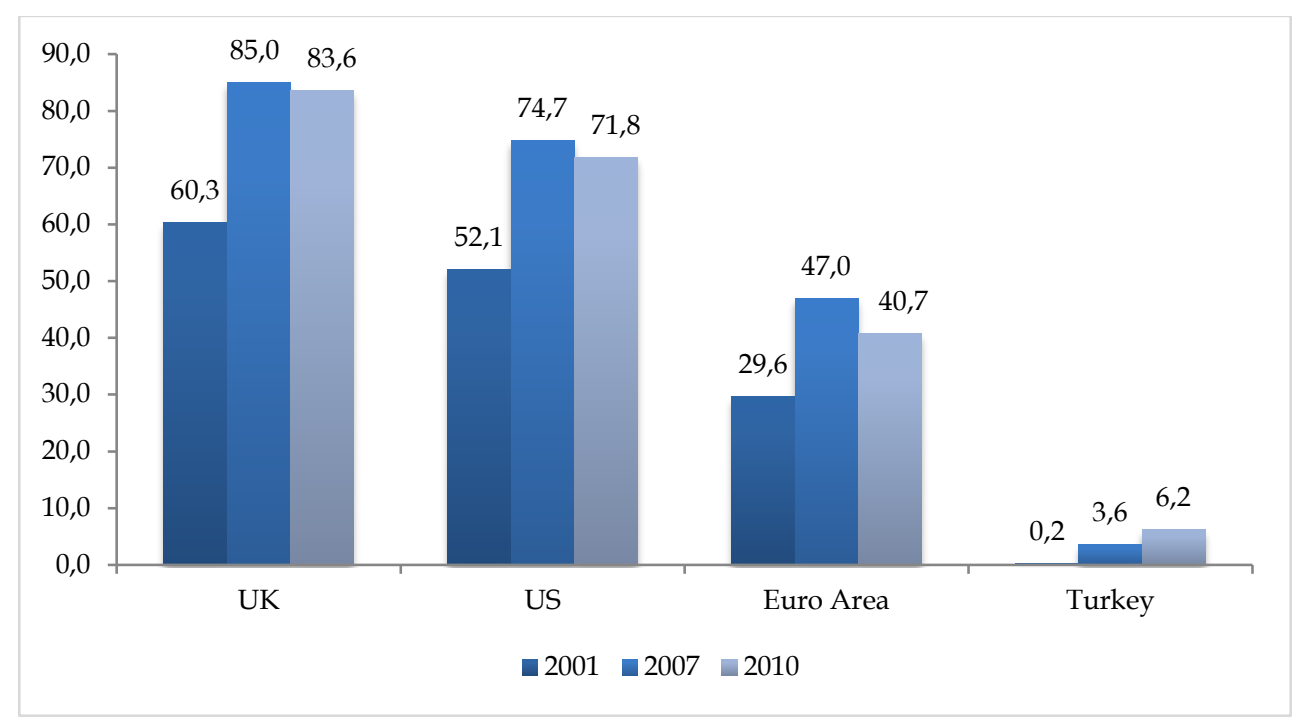

Figure 2: Share of Mortgage Market in GDP (\%)

On the other hand, the mortgage market share in GDP is too low in Turkey compared to other countries with well-developed mortgage systems. For example, as shown in Figure 2 (Ministry of Treasury and Finance, 2021), mortgage loans in 2010 amounted to only 6.2 per cent of the GDP, up from 3.6 per cent in 2007 in Turkey, while mortgage loans in the USA amounted to 71.8 per cent in 2010 even though there was a decrease after 2007 due to the global crisis triggered by the mortgage system in the country. Such a low portion in mortgaged sales is quite surprising for Turkey because an average of $7.5 \%$ of the GDP was accounted for in the last decade of real estate activities (TurkStat, 2021c). 
Another important issue about the Turkish economy is that the Turkish Lira has experienced a substantial loss of value since 2018 . The exchange rate reached US $\$ 4.64 /$ TL by mid-2018 and almost US\$6/TL in mid-2019, while it was US\$3.85/TL in December 2017 (CBRT, 2021a). As Ohno and Shimizu (2015) stated that currency depreciation might cause an increment in house prices, US Dollar/TL exchange rate is also included in this study as one of the critical indicators of the macroeconomic environment in the country.

\section{Data and empirical analysis}

The empirical analysis of this paper is based on monthly data for Turkey throughout 2010:M1 and 2020:M3. The period is determined by two criteria; (1) data availability and (2) avoiding the exogenous shocks of the COVID-19 pandemic on the economy. There is no doubt that the impact of variations in house prices is a significant component of a mortgage market. However, the official house price index produced by the Central Bank of the Republic of Turkey has been available only since 2010, which is the starting point of our analysis. Therefore, we restricted our data by March 2020, when the first COVID-19 positive case was detected in Turkey.

As Gross Domestic Product (GDP) is available every quarter, that is transformed into monthly data using the Chow-Lin method to match its periodicity to that of the other variables in the analysis. All information is taken from the Turkish Statistics Agency (TurkStat) or the Central Bank of Turkey (CBT). Table 2 explains the variables (in natural logarithms) and their summary statistics. ${ }^{3}$ Analyses are carried out by using Eviews 12 student version lite.

Table 2: Variable Definitions and Summary Statistics*

\begin{tabular}{|c|c|c|c|c|c|c|}
\hline \multirow[b]{2}{*}{ Variable } & \multirow[b]{2}{*}{ Definition } & \multicolumn{5}{|c|}{ Descriptive Statistics } \\
\hline & & Obs. & Mean & Std. Dev. & Min & $\operatorname{Max}$ \\
\hline MLV & Mortgage Loan Volume & 123 & 25.4936 & 0.4388 & 24.5441 & 26.0758 \\
\hline MG.RATE & $\begin{array}{l}\text { Weighted Average Interest } \\
\text { Rates For Housing Loans }\end{array}$ & 123 & 2.5409 & 0.2391 & 2.1160 & 3.3655 \\
\hline GDP & Gross Domestic Product & 123 & 4.9780 & 0.1711 & 4.5196 & 5.2575 \\
\hline IPI & Industrial Production Index & 123 & 4.5522 & 0.1808 & 4.0403 & 4.8688 \\
\hline HPI & Housing Price Index & 123 & 4.3049 & 0.3257 & 3.8044 & 4.8675 \\
\hline EXCHNG & $\begin{array}{l}\text { US Dollar-Turkish Lira } \\
\text { Exchange Rate }\end{array}$ & 123 & 0.9842 & 0.4538 & 0.3544 & 1.8529 \\
\hline UNEMP & Unemployment Rate & 123 & 2.3417 & 0.1582 & 1.9879 & 2.6878 \\
\hline NAGR.UNEMP & $\begin{array}{l}\text { Non-Agricultural } \\
\text { Unemployment Rate }\end{array}$ & 123 & 2.5246 & 0.1419 & 2.2083 & 2.8273 \\
\hline CONSTR & $\begin{array}{l}\text { Number of Construction } \\
\text { Permits }\end{array}$ & 123 & 10.9781 & 0.5410 & 9.1059 & 12.6973 \\
\hline OCCUP & Number of Occupancy Permits & 123 & 10.8906 & 0.3050 & 10.1108 & 11.6558 \\
\hline
\end{tabular}

${ }^{*}$ Note: all variables in natural logarithms.

\section{Unit root test and optimal lag length estimation}

Initially, the stationarity of all variables is tested with unit root tests. Then, the Augmented DickeyFuller (ADF) test, a parametric test for a unit root in time series data, is employed to determine the stationarity conditions of each variable at both level and first differences. ${ }^{4}$ The null hypothesis is that a unit root exists, which means non-stationary. The unemployment rate (UNEMP) and non-agricultural unemployment rate (NAGR.UNEMP) are excluded in the further analysis since they are stationary on the level stage, as seen in Table 3 .

\footnotetext{
${ }^{3}$ Consumer Price Index is not included in the analyses due to it is highly correlated with House Price Index.

${ }^{4}$ For the ADF tests, lag length is based on the Akaike Information Criterion (AIC).
} 


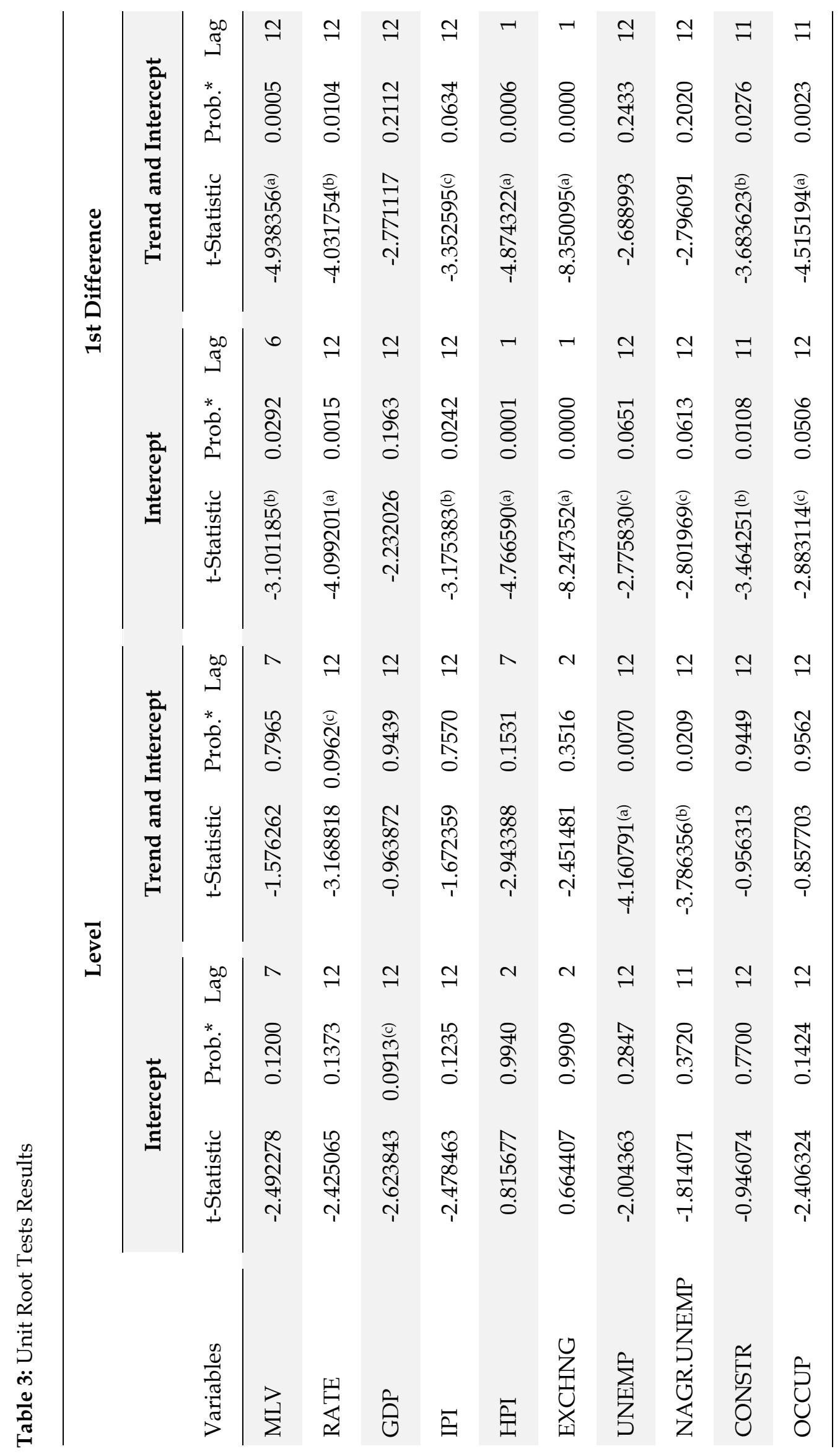

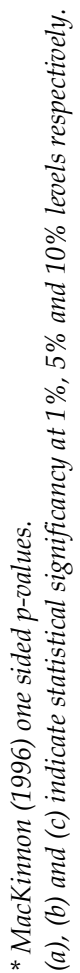


Because GDP is stationary at $10 \%$ level, economic development is represented with industrial production index (IPI), which has been used as a proxy for economic growth in some studies in the relevant literature (e.g. Uddin and Norman (2009), Ravazzolo and Vespignani (2015) and Singh, Devi, and Roy (2016)). The null hypothesis is rejected for the volume of mortgage loans (MLV), mortgage interest rates (MG.RATE), industrial production index (IPI), housing price index (HPI), US Dollar/Turkish Lira exchange rate (EXCHNG), number of residential properties getting construction permit (CONSTR) and occupancy permit (OCCUP) at first difference stage with both intercept and trend \& intercept. As there is a high correlation between CONSTR and OCCUP, CONSTR is chosen to be included in the further analysis. Therefore, econometric analyses are preceded with MLV, MG.RATE, IPI, HPI, EXCHNG and CONSTR indicators. Consequently, an empirical model can be formulated as below:

$$
M L V_{t}=\beta_{0}+\beta_{1} M G \cdot R A T E_{t}+\beta_{2} I P I_{t}+\beta_{3} H P I_{t}+\beta_{4} E X C H N G_{t}+\beta_{5} \operatorname{CONSTR}+\varepsilon_{t}
$$

In order to run a cointegration test, all variables need to be stationary at the same level. Unit root test using Augmented-Dickey Fuller (ADF) approach showed that all these five variables are non-stationary in level, but they are stationary in their first differences. Behaviours of the variables in level and their first differences are visualized in Figure 3 as well.
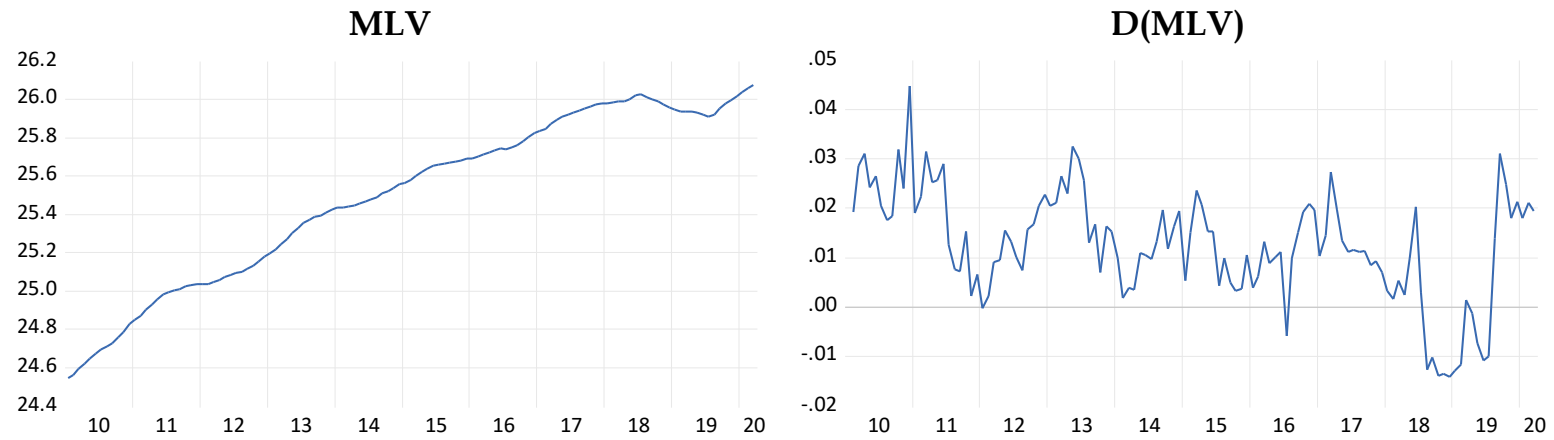

MG.RATE

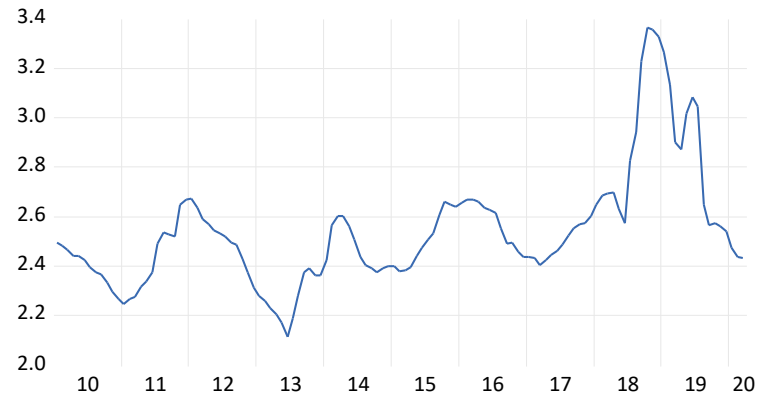

D(MG.RATE)

\section{HPI}
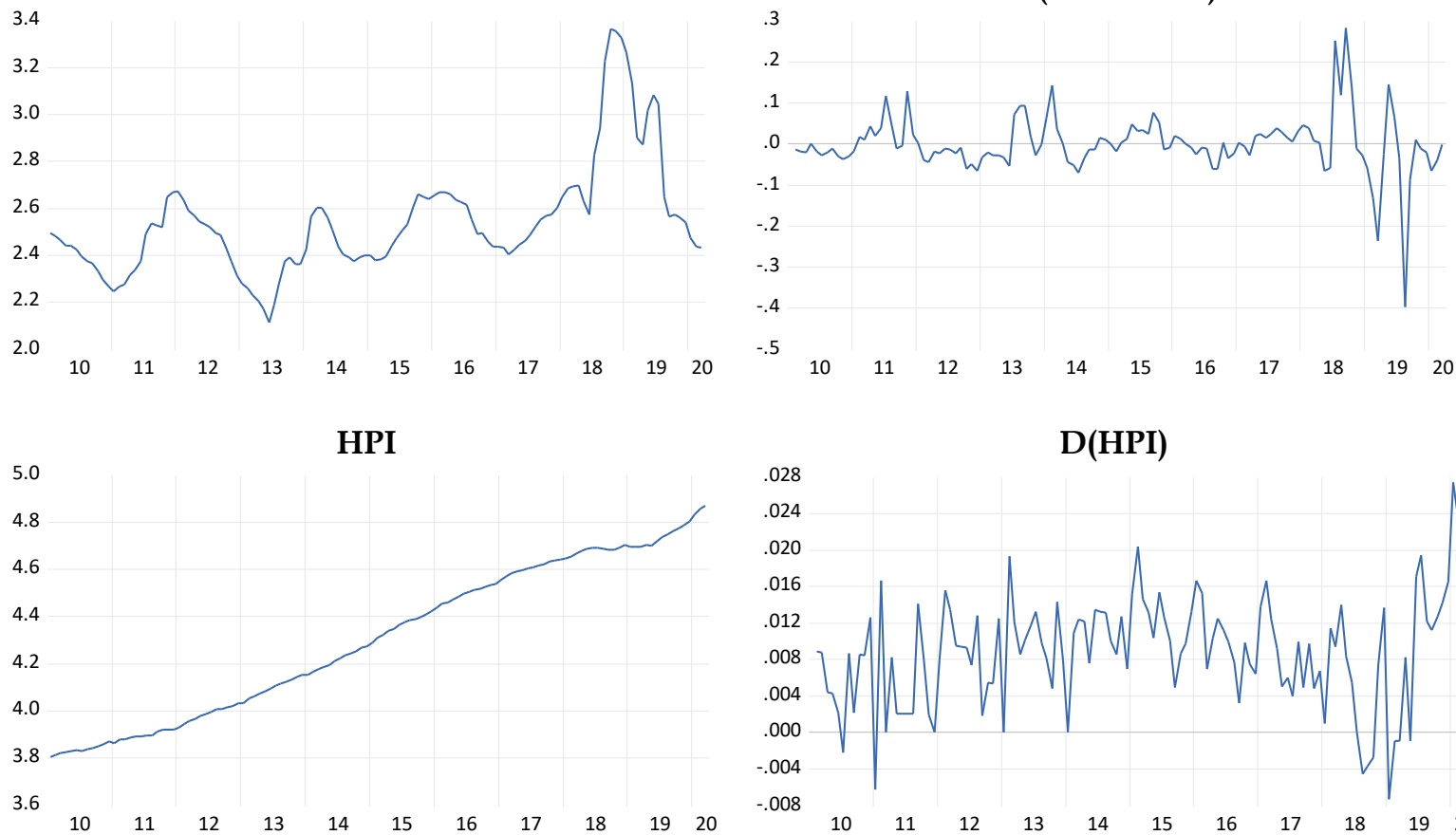

$\mathrm{D}(\mathrm{HPI})$

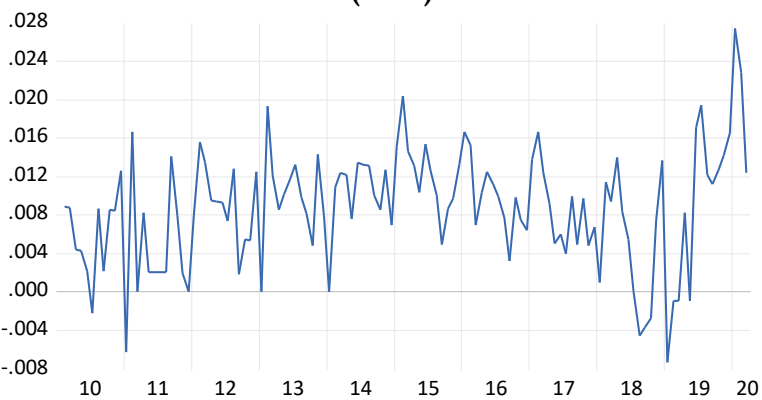

Figure 3: Graphs of the Variables (Level \& First Differences) (part 1/2) 

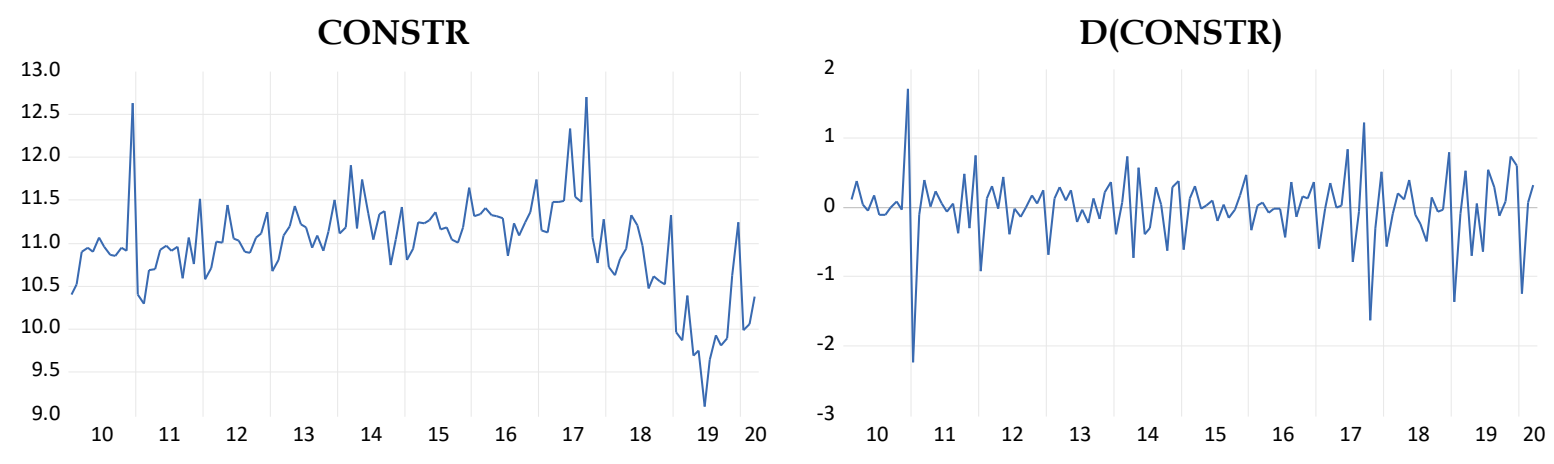

IPI

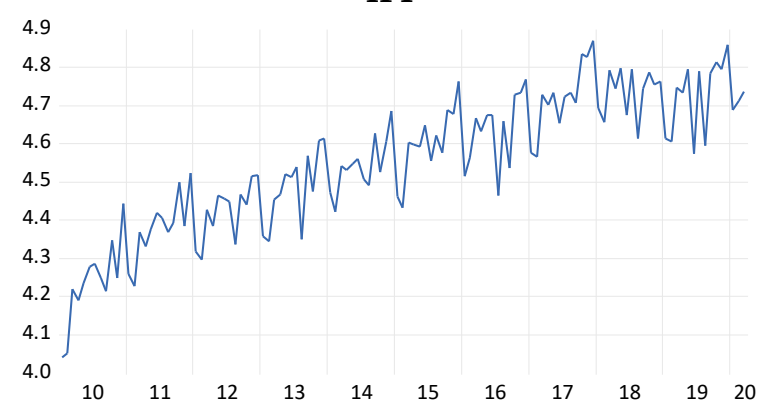

D(IPI)

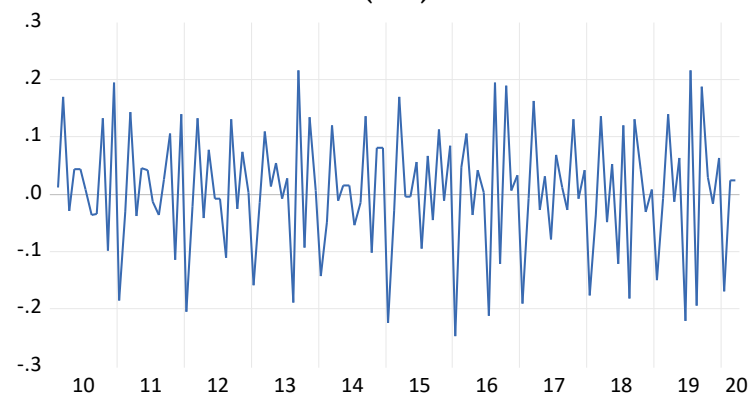

EXCHNG
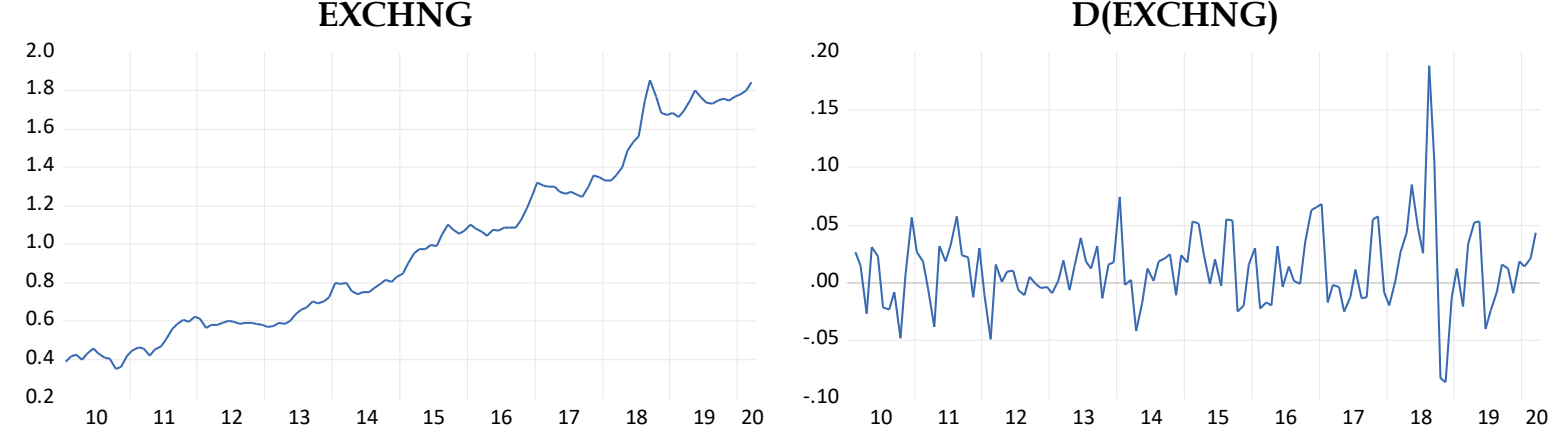

Figure 4: Graphs of the Variables (Level \& First Differences) (part 2/2)

A vector autoregressive (VAR) model is constructed to determine the number of lags, and the appropriate model for the data is selected. In this study, Akaike Information Criterion (AIC) chooses the number of lags. According to Table 4, optimum lag length is determined as 6, selected by three criteria out of five.

Table 4: Lag Order Selection Criteria

\begin{tabular}{ccccccc}
\hline Lag & LogL & LR & FPE & AIC & SC & HQ \\
\hline 0 & 354.8719 & NA & $9.84 \mathrm{e}-11$ & -6.015033 & -5.872606 & -5.957216 \\
1 & 1426.378 & 2013.693 & $1.74 \mathrm{e}-18$ & -23.86859 & $-22.87160^{*}$ & -23.46387 \\
2 & 1487.125 & 107.8786 & $1.14 \mathrm{e}-18$ & -24.29527 & -22.44371 & $-23.54364^{*}$ \\
3 & 1531.134 & 73.60045 & $1.00 \mathrm{e}-18$ & -24.43334 & -21.72723 & -23.33482 \\
4 & 1562.586 & 49.34647 & $1.11 \mathrm{e}-18$ & -24.45492 & -20.79425 & -22.90949 \\
5 & 1597.253 & 50.80532 & $1.18 \mathrm{e}-18$ & -24.33194 & -19.91670 & -22.53961 \\
6 & 1648.924 & $70.38029^{*}$ & $9.56 \mathrm{e}-19^{*}$ & $-24.60214^{*}$ & -19.33234 & -22.46290 \\
7 & 1683.535 & 43.56177 & $1.07 \mathrm{e}-18$ & -24.57819 & -18.45383 & -22.09205 \\
\hline${ }^{*}$ indicates lag order selected by criterion & & & &
\end{tabular}

The above acronyms indicate the following: LR: sequential modified LR test statistic (each test at 5\% level), FPE: Final prediction error, AIC: Akaike information criterion, SC: Schwarz information criterion and HQ: Hannan-Quinn information criterion. 


\section{Johansen cointegration test and vector error correction model (VECM)}

The Johansen cointegration test determines a co-integrating relationship and the number of cointegration vectors between the variables. Johansen (1995) proposed two statistics, the trace and maximum eigenvalue, to test the number of cointegration vectors. According to the Johansen Cointegration test results shown in Table 5 and Table 6, both trace and max-eigenvalue statistics demonstrate two co-integrating vectors at a $5 \%$ level. Therefore, VECM is used to determine the longrun relationship between mortgage volume and independent variables. Maysami and Koh (2000) recommend using the first eigenvector, which is based on the largest eigenvalue when more than one cointegration vector. Normalized co-integrating coefficients and relationships among the variables are shown in Table 7 and with equation (2).

Table 5: Unrestricted Cointegration Rank Test (Trace)

\begin{tabular}{|c|c|c|c|c|}
\hline $\begin{array}{l}\text { Hypothesized } \\
\text { No. of CE(s) }\end{array}$ & Eigenvalue & Trace Statistic & $\begin{array}{c}0.05 \\
\text { Critical Value }\end{array}$ & Prob. ** \\
\hline None* & 0.381634 & 132.8899 & 95.75366 & 0.0000 \\
\hline At most 1 * & 0.275822 & 77.13163 & 69.81889 & 0.0116 \\
\hline At most 2 & 0.155540 & 39.69629 & 47.85613 & 0.2336 \\
\hline At most 3 & 0.112559 & 20.08554 & 29.79707 & 0.4171 \\
\hline At most 4 & 0.041122 & 6.233614 & 15.49471 & 0.6679 \\
\hline At most 5 & 0.011678 & 1.362662 & 3.841465 & 0.2431 \\
\hline $\begin{array}{l}\text { Trace test indicate } \\
{ }^{*} \text { denotes rejection } \\
{ }^{* *} \text { MacKinnon-Ha }\end{array}$ & $\begin{array}{l}\text { tegrating eqn(s) } \\
\text { othesis at the } 0.0 \\
\text { (1999) p-values }\end{array}$ & ele 0.05 level & & \\
\hline
\end{tabular}

Table 6: Unrestricted Cointegration Rank Test (Maximum Eigenvalue)

\begin{tabular}{lcccc}
\hline \hline $\begin{array}{l}\text { Hypothesized } \\
\text { No. of CE(s) }\end{array}$ & Eigenvalue & $\begin{array}{c}\text { Max-Eigen } \\
\text { Statistic }\end{array}$ & $\begin{array}{c}0.05 \\
\text { Critical Value }\end{array}$ & Prob. ** \\
\hline None * & 0.381634 & 55.75832 & 40.07757 & 0.0004 \\
At most 1 * & 0.275822 & 37.43534 & 33.87687 & 0.0180 \\
At most 2 & 0.155540 & 19.61074 & 27.58434 & 0.3687 \\
At most 3 & 0.112559 & 13.85193 & 21.13162 & 0.3773 \\
At most 4 & 0.041122 & 4.870953 & 14.26460 & 0.7581 \\
At most 5 & 0.011678 & 1.363662 & 3.841465 & 0.2431 \\
\hline $\begin{array}{l}\text { Trace test indicates two co-integrating eqn(s) at the 0.05 level } \\
\text { * }{ }^{*} \text { denotes rejection of the hypothesis at the 0.05 level }\end{array}$ \\
* MacKinnon-Haug-Michelis (1999) p-values \\
\hline \hline
\end{tabular}

Table 7: Normalized co-integrating coefficients and VECM Equation

\begin{tabular}{lccccc}
\hline MLV & MRTG.RATE & HPI & CONSTR & IPI & EXCHNG \\
\hline 1.000000 & $1.085914^{*}$ & $-3.281257^{*}$ & $0.472330^{*}$ & -0.749077 & $1.773601^{*}$ \\
& $(0.36719)$ & $(0.49891)$ & $(0.08233)$ & $(0.60319)$ & $(0.39117)$ \\
& {$[2.95738]$} & {$[-6.57689]$} & {$[5.73726]$} & {$[-1.24187]$} & {$[4.53407]$} \\
\hline
\end{tabular}

$$
\begin{gathered}
M L V=17.66063-1.085914 * M G . R A T E+3.281257 * H P I-0.472330 * \text { CONSTR }+ \\
0.749077 * I P I-1.773601 * \text { EXCHNG }
\end{gathered}
$$

Table 7 and Equation (2) clearly show a significant long-run relationship between the volume of mortgage loans and independent variables taken into the model. The signs of all variables are consistent with the expectations in theory. In other words, it is expected that the volume of mortgage loans will decrease if the mortgage interest rates and US Dollar/Turkish Lira exchange rate increase. Similarly, 
there is a negative relationship between the supply of new real properties and mortgage volume while mortgage volume is positively related to house prices and the industrial production index. The coefficients, except for IPI, are statistically significant, and it seems that compared to the other four macroeconomic variables, HPI has the most significant impact on the volume of mortgage loans. US Dollar-Turkish Lira exchange rate and mortgage interest rate are the other significantly important indicators after the HPI on the housing credit size. These results are reasonable as the lower the interest rates are, the more attractive mortgage loans are. Rising exchange rates may make people hesitate to become indebted to banks for sizeable loans with longer terms.

Table 8: Vector Error Correction Model

\begin{tabular}{|c|c|c|c|c|}
\hline & Coefficient & Std. Error & t-statistic & p-value \\
\hline CointEq1 $(\lambda)$ & -0.020182 (a) & $(0.00554)$ & {$[-3.64465]$} & 0.0003 \\
\hline $\mathrm{D}(\operatorname{MLV}(-1))$ & 0.211901 & $(0.15389)$ & [ 1.37698$]$ & 0.1692 \\
\hline $\mathrm{D}(\operatorname{MLV}(-2))$ & 0.316893 (c) & $(0.17108)$ & [ 1.85229] & 0.0646 \\
\hline $\mathrm{D}(\operatorname{MLV}(-3))$ & -0.212627 & $(0.17973)$ & [-1.18307] & 0.2374 \\
\hline $\mathrm{D}(\operatorname{MLV}(-4))$ & 0.270559 & $(0.18186)$ & [ 1.48776$]$ & 0.1375 \\
\hline $\mathrm{D}(\operatorname{MLV}(-5))$ & -0.230708 & $(0.18106)$ & {$[-1.27421]$} & 0.2032 \\
\hline $\mathrm{D}(\mathrm{MLV}(-6))$ & 0.089642 & $(0.15638)$ & [ 0.57322] & 0.5668 \\
\hline $\mathrm{D}(\operatorname{RATE}(-1))$ & -0.049091 (a) & $(0.01463)$ & {$[-3.35447]$} & 0.0009 \\
\hline D(RATE $(-2))$ & 0.027322 (c) & $(0.01561)$ & [ 1.75032$]$ & 0.0807 \\
\hline D(RATE (-3) & 0.001067 & $(0.01584)$ & [ 0.06736] & 0.9463 \\
\hline D(RATE (-4) & 0.004613 & $(0.01517)$ & [ 0.30414$]$ & 0.7612 \\
\hline D(RATE (-5) & -0.014812 & $(0.01660)$ & {$[-0.89253]$} & 0.3726 \\
\hline D(RATE (-6) & 9.94E-05 & $(0.01030)$ & [ 0.00964$]$ & 0.9923 \\
\hline D(HPI (-1)) & 0.003422 & $(0.11733)$ & [ 0.02916] & 0.9767 \\
\hline $\mathrm{D}(\mathrm{HPI}(-2))$ & -0.022214 & (0.11959) & {$[-0.18575]$} & 0.8527 \\
\hline D(HPI (-3)) & -0.155965 & $(0.12210)$ & [-1.27733] & 0.2021 \\
\hline D(HPI (-4)) & -0.055058 & $(0.11530)$ & {$[-0.47753]$} & 0.6332 \\
\hline D(HPI (-5)) & -0.181616 & $(0.11208)$ & {$[-1.62034]$} & 0.1058 \\
\hline D(HPI (-6)) & -0.092968 & $(0.11675)$ & {$[-0.79627]$} & 0.4263 \\
\hline $\mathrm{D}(\mathrm{CONSTR}(-1))$ & $0.006751^{(b)}$ & $(0.00271)$ & [ 2.48874] & 0.0132 \\
\hline $\mathrm{D}(\mathrm{CONSTR}(-2))$ & 0.004749 (c) & $(0.00267)$ & [ 1.78059] & 0.0756 \\
\hline D(CONSTR $(-3))$ & $0.006325^{(b)}$ & $(0.00270)$ & [ 2.34525] & 0.0194 \\
\hline $\mathrm{D}(\mathrm{CONSTR}(-4))$ & 0.004285 & $(0.00278)$ & [ 1.54171$]$ & 0.1238 \\
\hline $\mathrm{D}(\mathrm{CONSTR}(-5))$ & 0.005037 (b) & $(0.00235)$ & [ 2.14117] & 0.0328 \\
\hline D(CONSTR (-6)) & 0.004017 (b) & $(0.00178)$ & [ 2.26020] & 0.0243 \\
\hline $\mathrm{D}(\mathrm{IPI}(-1))$ & -0.030049 (a) & $(0.00883)$ & {$[-3.40251]$} & 0.0007 \\
\hline D(IPI (-2)) & -0.044768 (a) & $(0.01166)$ & {$[-3.83981]$} & 0.0001 \\
\hline D(IPI (-3)) & -0.029475 (b) & $(0.01169)$ & {$[-2.52077]$} & 0.0120 \\
\hline D(IPI (-4)) & -0.048153 (a) & $(0.01090)$ & {$[-4.41631]$} & 0.0000 \\
\hline D(IPI (-5)) & -0.030304 (b) & (0.01199) & {$[-2.52655]$} & 0.0118 \\
\hline $\mathrm{D}(\mathrm{IPI}(-6))$ & -0.010575 & $(0.00922)$ & {$[-1.14750]$} & 0.2518 \\
\hline $\mathrm{D}(\mathrm{EXCHNG}(-1))$ & -0.005798 & $(0.01655)$ & {$[-0.35026]$} & 0.7263 \\
\hline $\mathrm{D}(\mathrm{EXCHNG}(-2))$ & 0.018652 & $(0.02074)$ & [ 0.89938] & 0.3689 \\
\hline $\mathrm{D}(\mathrm{EXCHNG}(-3))$ & 0.005386 & $(0.02057)$ & [ 0.26185] & 0.7936 \\
\hline $\mathrm{D}(\mathrm{EXCHNG}(-4))$ & 0.012635 & $(0.02100)$ & [ 0.60167$]$ & 0.5477 \\
\hline $\mathrm{D}(\mathrm{EXCHNG}(-5))$ & 0.001603 & $(0.01927)$ & [ 0.08318$]$ & 0.9337 \\
\hline $\mathrm{D}(\mathrm{EXCHNG}(-6))$ & 0.028820 & $(0.01877)$ & [ 1.53529$]$ & 0.1254 \\
\hline $\mathrm{C}$ & 0.011197 (a) & $(0.00323)$ & [3.46269] & 0.0006 \\
\hline R-squared & \multicolumn{4}{|c|}{0.876004} \\
\hline Adj. R-squared & \multicolumn{4}{|c|}{0.817185} \\
\hline Durbin-Watson stat & \multicolumn{4}{|c|}{2.032388} \\
\hline
\end{tabular}


Vector error correction models (VECM) provide the error correction terms (ECT), which measure the speed of adjustments towards long-run equilibrium and short-run parameters. Table 8 presents the short-run dynamics based on the VECM estimates. ECT is calculated as -0.020410 and found to be statistically significant with the expected negative sign theoretically. The estimated ECT means that around $2.04 \%$ of the short-run deviations of mortgage loans volume would be adjusted each period towards the long-run equilibrium.

Table 9 shows residual diagnostics tests conducted for the assumptions regarding normality, heteroskedasticity and serial correlation. According to the Jarque-Bera test for normality (Orthogonalization: Cholesky- Lutkepohl), residuals are generally distributed except the EXCHNG variable. This might stem from the steep depreciation of the Turkish Lira against the US Dollar in recent years. The autocorrelation LM test results indicate no autocorrelation in this model. The WhiteHeteroskedasticity test proves that this model is not Heteroskedastic. Residual stability of VECM is checked with inverse roots of AR Characteristic polynomial. As seen in Figure 4, all origins are less than one and within the unit circle; therefore, our model meets the stability conditions. In general, these results ensure the validity of our model.

Table 9: Residual Diagnostics Tests

\begin{tabular}{ll}
\hline \multicolumn{2}{c}{ Normality } \\
\hline & Jarque-Bera \\
\hline MLV & 0.5191 \\
RATE & 0.2705 \\
HPI & 0.8867 \\
CONSTR & 0.2097 \\
IPI & 0.4306 \\
EXCHNG & 0.0001 \\
\hline
\end{tabular}

\begin{tabular}{cl}
\hline \multicolumn{2}{c}{$\begin{array}{c}\text { Serial } \\
\text { Correlation }\end{array}$} \\
\hline Lags & LM-Stat \\
\hline 1 & 0.6825 \\
2 & 0.2782 \\
3 & 0.5644 \\
4 & 0.1098 \\
5 & 0.2006 \\
6 & 0.3326 \\
\hline
\end{tabular}

\begin{tabular}{l}
\begin{tabular}{l} 
White- \\
Heteroskedasticity \\
\hline 0.5896
\end{tabular} \\
\hline
\end{tabular}

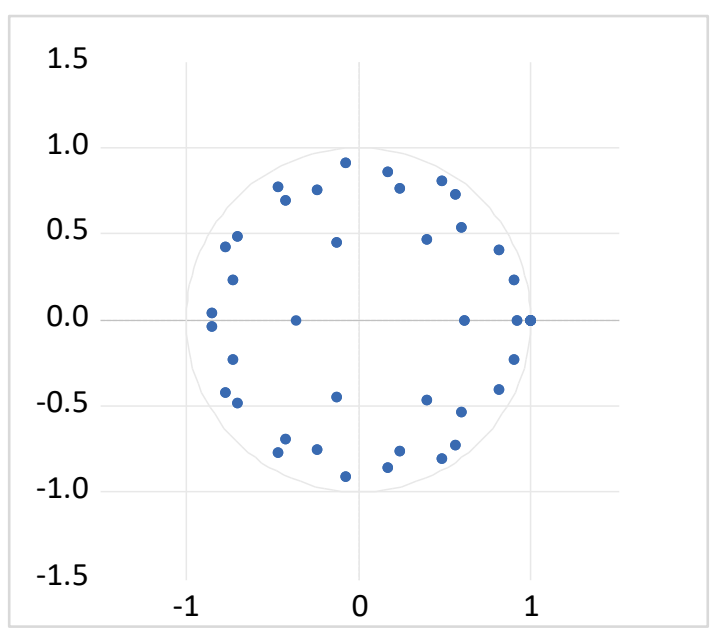

Figure 5: Inverse Roots of AR Characteristic Polynomial

Granger Causality Test, firstly proposed by Granger in 1969 (Kirchgässner, Wolters, \& Hassler, 2012), is carried out to determine the causality relationship between the static variables. As seen in Table 10, all independent variables are the Granger cause of the dependent variable, volume of mortgage loans. These causal relationships are bidirectional for all variables, except mortgage interest rates. There is a one-way causality relationship from mortgage rates to mortgage loan volume. 
Table 10: Granger Causality Tests

\begin{tabular}{|c|c|c|c|}
\hline Null Hypothesis & F-Statistic & Prob. & Causality \\
\hline D(RATE) does not Granger Cause D(MLV) & 13.6353 (a) & 2.E-11 & \multirow{2}{*}{$\mathrm{RATE} \rightarrow \mathrm{MLV}$} \\
\hline D(MLV)does not Granger Cause D(RATE) & 1.56804 & 0.1639 & \\
\hline D(HPI) does not Granger Cause D(MLV) & 3.30450 (a) & 0.0051 & \multirow{2}{*}{$\mathrm{HPI} \leftrightarrow \mathrm{MLV}$} \\
\hline D(MLV)does not Granger Cause D(HPI) & $2.34642(b)$ & 0.0365 & \\
\hline D(CONSTR) does not Granger Cause D(MLV) & $2.14024^{(\mathrm{c})}$ & 0.0549 & \multirow{2}{*}{ CONSTR $\leftrightarrow \mathrm{MLV}$} \\
\hline D(MLV)does not Granger Cause D(CONSTR) & $2.83636(b)$ & 0.0135 & \\
\hline D(IPI) does not Granger Cause D(MLV) & 6.91842 (a) & 3.E-06 & \multirow{2}{*}{$\mathrm{IPI} \leftrightarrow \mathrm{MLV}$} \\
\hline D(MLV)does not Granger Cause D(IPI) & $3.38214(a)$ & 0.0044 & \\
\hline $\mathrm{D}(\mathrm{EXCHNG})$ does not Granger Cause D(MLV) & $2.56792(b)$ & 0.0233 & \multirow{2}{*}{$\mathrm{EXCHNG} \leftrightarrow \mathrm{MLV}$} \\
\hline D(MLV)does not Granger Cause D(EXCHNG) & 1.97675 (c) & 0.0757 & \\
\hline
\end{tabular}

\section{Impulse response function and variance decomposition analyses}

The impulse response function is used to measure the responsiveness of the dependent variable in the vector error correction model towards macroeconomic shocks. One problem with the impulse response analysis is the sensitiveness of variable ordering. The ordering of the variables cannot be determined with a statistical method. It has to be specified by the analyst. In this paper, various arrangements are tried and seen that results are pretty consistent. Impulse response graphs are seen in Figure 5 based on the "MLV, MG.RATE, HPI, CONSTR, IPI, EXCHNG" Cholesky ordering.

Figure 5 shows the response of mortgage loan volume to one standard deviation shock to all independent variables in our model. A positive shock to mortgage interest rates (MG.RATE), number of construction permits (CONSTR), and USD/TL Exchange rate is associated with a negative effect on MLV volatility. In contrast, the response of mortgage volume to an impulse in house price is favourable. On the other hand, it is hard to say that Turkish mortgage volume significantly responds to a shock in the industrial production index, consistent with the vector error correction model, equation (2).

Variance decomposition is used to identify the response of dependent variables due to their shocks and shocks from other variables in the meantime. Generally, impulse response and variance decomposition analysis offer very similar information. The variance decomposition of MLV is shown in Table 11. Results of impulse response and variance decomposition are consistent with each other. USD/TL exchange rate, a weighted average of mortgage interest rates, housing prices, and a number of construction permits have significantly significant impacts on explaining the volume of mortgage loans in the Turkish market. 


\begin{tabular}{l|l|l|l|l|l|}
\hline & Response of MLV to MG.RATE & & & \\
\hline
\end{tabular}

Figure 6: Impulse Response Graphs

Table 11: Variance Decomposition of MLV

\begin{tabular}{cccccccc}
\hline $\begin{array}{c}\text { Variance } \\
\text { Period }\end{array}$ & S.E. & MLV & MG.RATE & HPI & CONSTR & IPI & EXCHNG \\
\hline 1 & 0.004752 & 100.0000 & 0.000000 & 0.000000 & 0.000000 & 0.000000 & 0.000000 \\
2 & 0.008568 & 79.69536 & 15.43211 & 0.452766 & 1.032150 & 1.360338 & 2.027283 \\
3 & 0.013230 & 58.86115 & 23.81561 & 1.844292 & 2.358810 & 1.334490 & 11.78564 \\
4 & 0.018610 & 44.39188 & 25.40915 & 3.532589 & 2.973940 & 1.279748 & 22.41269 \\
5 & 0.025020 & 34.52393 & 22.73794 & 5.255737 & 4.007763 & 1.332889 & 32.14173 \\
6 & 0.032229 & 28.32881 & 20.96596 & 6.176639 & 4.437778 & 0.926487 & 39.16432 \\
7 & 0.039980 & 26.42315 & 19.26338 & 6.160242 & 4.276295 & 0.610783 & 43.26615 \\
8 & 0.047955 & 24.65121 & 19.06028 & 5.678308 & 4.622403 & 0.424760 & 45.56304 \\
9 & 0.055821 & 22.91624 & 19.03290 & 5.119512 & 5.049788 & 0.313485 & 47.56807 \\
10 & 0.063447 & 21.84031 & 18.83328 & 4.678717 & 5.252894 & 0.269835 & 49.12496 \\
\hline
\end{tabular}

Cholesky Ordering: MLV MG.RATE HPI CONSTR IPI EXCHNG 


\section{Conclusion}

The main objective of this study is to examine the impacts of some selected key macroeconomic factors on the growth of mortgage loans in Turkey. In addition to mortgage interest rates, housing prices, construction permits and industrial production index, the USD/TL exchange rate is included in the analysis to reflect the Turkish Lira's depreciation against the US Dollars. It is found that there is a longrun relationship among these variables, and the level of house prices has the most significant impact on housing credit volume. Exchange rate, mortgage rate, and construction permits are the other significantly essential variables, while the industrial production index is not statistically significant in the vector error correction model.

As housing prices increase, the volume of housing loans increases. This positive relationship is also valid for the industrial production index. Similar results were found in the relevant literature, e.g. housing loan volume is positively correlated with HPI and GDP in Singapore (Addae-Dapaah, 2014). Stable prices and economic growth are undoubtedly among the main pillars of mortgage markets, shown by Shukor et al. (2016) in Malaysia. On the other hand, mortgage interest rates and credit volume are negatively correlated, consistent with theoretical anticipation because mortgage rates significantly impact the cost of home purchases through mortgage loans. Turkey is one of those countries where mortgage interest rates are pretty high, and high speeds have a substantially decelerating impact on the mortgage market growth in the country. Like other emerging mortgage markets globally, the Turkish mortgage market is depository-based, and lending institutions' funding costs are pretty high. Due to the instability in the economic conditions in the long term, banks need to challenge liquidity and interest risks, which makes mortgage loans expensive for people. Many country experiences have proved that capital markets provide attractive fund sources for lenders (Chiquier, Hassler, \& Lea, 2004). Therefore, Turkey needs to achieve a sound secondary mortgage market, which is an essential component to avoid the adverse effect of the maturity gap, provide mortgage loans with lower interest rates for long terms, and consequently expand the mortgage market size.

It should also be noted that there are interactions among economic indicators and the mortgage market. For instance, decreasing mortgage rates may cause credit expansion initially; however, rapid home sales may bring a rising trend in mortgage rates, which diminishes housing affordability for people. On the other hand, increasing mortgage rate trends may slow housing price appreciation down and bring a balance to the market by keeping house prices within reach (Fabozzi, Bhattacharya, \& Berliner, 2011). Moreover, a number of construction permits have a negative relationship with the mortgage volume, which seems contradicted with theoretical expectations; however, as Kohl (2021) stated, mortgage credits and new constructions are nonlinearly associated with each other: "positive up to a threshold, negative after that." Besides, interactions with other market drivers, such as rental prices, government interventions, public houses, and locational differences, may impact the mortgage size.

For the primary and secondary mortgage market, legislative regulations enacted in Turkey may serve as blueprints for a well-developed mortgage system. However, the findings of this study, including the negative correlation found between the USD/TL exchange rate and mortgage volume, are indicators of the importance of stability in the economy for mortgage market growth. Therefore, Turkey needs to keep in mind that macroeconomic stability is not a buzzword to ensure the development and maintenance of its housing system in a sound environment. Therefore, these results make further analysis focusing on macroeconomic studies a priority for Turkey. Furthermore, to focus specifically on the mortgage market, comparative studies involving Turkish and similar emerging markets and lessons learned from the countries' experiences with well-developed mortgage markets will provide essential contributions in both literature and policymakers.

\section{Peer-review:}

Externally peer-reviewed

\section{Conflict of interests:}

The authors have no conflict of interest to declare.

\section{Author Contributions:}

Idea/Concept/Design: T.G., A.A. Data Collection and/or Processing: T.G. Analysis and/or Interpretation: T.G., A.A. Literature Review: T.G. Writing the Article: T.G., A.A. Critical Review: T.G., A.A. Approval: T.G., A.A. 


\section{References}

Adams, Z., \& Füss, R. (2010). Macroeconomic determinants of international housing markets. Journal of Housing Economics, 19(1), 38-50.

Addae-Dapaah, K. (2014). Housing loan and the price of housing in Singapore. Journal of Business and Economics, 5(9), 1513-1524.

Ahiadorme, J. W. (2016). Assessing the Interaction between the Macro Economy and the Mortgage Market: Evidence from Ghana. International Journal of Contemporary Applied Sciences, 3(10), 40-53.

Akkay, R. C. (2021). The Macroeconomic Determinants of The Housing Prices in Turkey. Erciyes Üniversitesi İktisadi ve İdari Bilimler Fakültesi Dergisi(58), 241-264.

Arestis, P., \& González, A. R. (2014). Modelling the housing market in OECD countries. International Review of Applied Economics, 28(2), 131-153.

Calza, A., Gartner, C., \& Sousa, J. (2001). Modelling the demand for loans to the private sector in the Euro area. No. 55. Retrieved from

CBRT. (2021a). Exchange Rates, https://evds2.tcmb.gov.tr/index.php?/evds/serieMarket.

CBRT. (2021b). Weighted Average Interest Rates For Banks Loans, The Central Bank of the Republic of Turkey, https://evds2.tcmb.gov.tr/index.php?/evds/serieMarket.

Chiquier, L., Hassler, O., \& Lea, M. (2004). Mortgage securities in emerging markets. World Bank Policy Research Working Paper(3370).

Chiquier, L., \& Lea, M. J. (2009). Housing finance policy in emerging markets: World Bank Publications.

Coskun, Y. (2016). Konut fiyatlari ve yatirimi: Türkiye için bir analiz. Niğde Üniversitesi İktisadi ve İdari Bilimler Fakültesi Dergisi, 9(2), 201-217.

Dajcman, S. (2020). Demand for residential mortgage loans and house prices in the Euro Area. Economics \& Sociology, 13(1), 40-51.

Duan, J., Tian, G., Yang, L., \& Zhou, T. (2021). Addressing the macroeconomic and hedonic determinants of housing prices in Beijing Metropolitan Area, China. Habitat International, 113, 102374.

Erjona, R. (2014). Mortgage lending and house prices in Albania-a co-integrated analysis based on VECM. Eastern Journal of European Studies, 5(1), 79-98.

Fabozzi, F. J., Bhattacharya, A. K., \& Berliner, W. S. (2011). Mortgage-backed securities: products, structuring, and analytical techniques (Vol. 200): John Wiley \& Sons.

Freddie Mac. (2021). Primary Mortgage Market Survey, http://www.freddiemac.com/pmms/.

Gattin-Turkalj, K., Ljubaj, I., Martinis, A., \& Mrkalj, M. (2007). Estimating credit demand in Croatia. Croatian National Bank Paper, 1-36.

Güneş, T., \& Yildiz, Ü. (2016). Property valuation and taxation for improving local governance in Turkey. Land tenure journal, 15(2), 141-160.

Habitat. (2021). Housing ensures sustainable development, SDG Booklet, .

Hepsen, A., \& Bas, N. K. (2009). Housing market activity and macroeconomic variables: an analysis of Turkish dwelling market under new mortgage system. İstanbul Üniversitesi İşletme Fakültesi Dergisi, $38(1), 38-46$.

Hort, K. (1998). The determinants of urban house price fluctuations in Sweden 1968-1994. Journal of Housing Economics, 7(2), 93-120.

Hülagü, T., Kızılkaya, E., Özbekler, A., \& Tunar, P. (2016). Türkiye Konut Fiyat Endeksi'nin Kalite Değişimi Etkisinden Arındırılması: Hedonik Konut Fiyat Endeksi. TCMB Ekonomi Notları, 1-15.

İbicioğlu, M., \& Karan, M. B. (2012). Konut kredisi talebini etkileyen faktörler: Türkiye üzerine bir uygulama. Ekonomi Bilimleri Dergisi, 4(1), 65-75.

Jen-Shi, N., Shuen-Shi, H., \& Yu, W. (2012). Interest rate, Unemployment rate, and Housing Market in US. Journal of Modern Accounting and Auditing, 8(6), 837.

Johansen, S. (1995). Likelihood-based inference in co-integrated vector autoregressive models: Oxford University Press on Demand. 
Karadaş, H. A., \& Salihoğlu, E. (2020). Seiçili Makroekonomik Değişkenlerin Konut Fiyatlarina Etkisi: Türkiye Örneği. Ekonomik ve Sosyal Araştırmalar Dergisi, 16(1), 63-80.

Kirchgässner, G., Wolters, J., \& Hassler, U. (2012). Introduction to modern time series analysis: Springer Science \& Business Media.

Kohl, S. (2021). Too much mortgage debt? The effect of housing financialization on housing supply and residential capital formation. Socio-Economic Review, 19(2), 413-440.

Maysami, R. C., \& Koh, T. S. (2000). A vector error correction model of the Singapore stock market. International Review of Economics \& Finance, 9(1), 79-96.

Ministry of Treasury and Finance. (2021). Turkish Economy, Republic of Turkey Ministry of Treasury and Finance, https://ms.hmb.gov.tr/uploads/2021/09/Ekonomi_Sunumu.pdf.

Mogaka, A. J., Kiweu, J. M., \& Kamau, R. G. (2015). The influence of macro economic factors on mortgage market growth in Kenya. Journal of Finance and Accounting, 3(4), 77-85

Naoi, M., Tiwari, P., Moriizumi, Y., Yukutake, N., Hutchison, N., Koblyakova, A., \& Rao, J. (2019). Household mortgage demand: a study of the UK, Australia and Japan. International Journal of Housing Markets and Analysis.

Ohno, S., \& Shimizu, J. (2015). Do exchange rate arrangements and capital controls influence international capital flows and housing prices in Asia? Journal of Asian Economics, 39, 1-18.

Panagiotidis, T., \& Printzis, P. (2016). On the macroeconomic determinants of the housing market in Greece: A VECM approach. International Economics and Economic Policy, 13(3), 387-409.

Ramesh, A., \& Kumar, S. (2017). Macro Economic Determinants of Bad Loans in Indian Mortgage Market. International Journal of Economic Research, 14(14), 285-290.

Ravazzolo, F., \& Vespignani, J. (2015). A new monthly indicator of global real economic activity.

Renaud, B. (1999). The financing of social housing in integrating financial markets: a view from developing countries. Urban Studies, 36(4), 755-773.

Shahini, I. (2014). The impact of economic growth in housing loans demand in Albania. European Scientific Journal, 10(19).

Shukor, N. B. B. M., Said, R. B., \& Majid, R. B. A. (2016). The Relationship between Housing Finance and Macroeconomics Variables in Malaysia. Paper presented at the MATEC Web of Conferences.

Singh, S. S., Devi, T. L., \& Roy, T. D. (2016). Time series analysis of index of industrial production of India. IOSR J. Math, 12(3), 1-7.

TurkStat. (2021a). Address Based Population Registration System, https://biruni.tuik.gov.tr/medas/?kn=95\&locale=en.

TurkStat. (2021b). Building Permit Statistics, https:// biruni.tuik.gov.tr/yapiizin/giris.zul?dil=ing.

TurkStat. (2021c). GDP in Turkey, data.tuik.gov.tr/Bulten/Index?p=Donemsel-Gayrisafi-Yurt-IciHasila-I.-Ceyrek:-Ocak---Mart,-2021-37181

TurkStat. (2021d). House Sale Statistics, https:// biruni.tuik.gov.tr/medas/?kn=95\&locale=en.

Ucal, M. S., \& Gőkkent, G. (2009). Macroeconomic Factors Affecting Real Estate Markets in Turkey: A VAR Analysis Approach. Briefing Notes in Economics, 80.

Uddin, M. G. S., \& Norman, A. (2009). Causality between Industrial Production and Exports in Bangladesh. The Global Journal of Finance and Economics, 8(3), 77-87.

Uysal, D., \& Yiğit, M. (2016). Determinants of housing demand in Turkey (1970-2015): an empirical study. Selçuk University Journal of Vocational School of Social Sciences, 1(19), 185-209.

Warnock, V. C., \& Warnock, F. E. (2008). Markets and housing finance. Journal of Housing Economics, 17(3), 239-251.

Yalciner, K. (2006). İpotek Karşılığı Menkulleştirilmiş Krediler Mortgage (İKMEK-MORTGAGE): Gazi Kitabevi.

Yalciner, K., \& Coskun, Y. (2014). Conditions of mortgage market development: a critical Emprical review for Turkey. 